\title{
ANAEROBİK ÇÜRÜTÜCÜ ATIKSULARININ MİKROALG REAKTÖRLERINDE ARITILMASI
}

\author{
Ülker Diler KERIŞSSEN"
}

Alınma: 21.02.2019; düzeltme:13.05.2019; kabul: 15.05.2019

\begin{abstract}
Öz: Bu çalışma evsel nitelikli anaerobik çürütücü atıksuyunun (AÇAS) evsel nitelikli atık suların alıcı ortam deşarj standartlarına uygun düzeyde arıtılmasında bakteri ve mikroalg kültürlerinin birlikte ve ayrı ayrı kullanılmasının arıtım verimliliği üzerindeki etkisini incelemek üzere yürütülmüştür. Bakteri ve mikroalg kültürlerinin birlikte kullanıldığı, AÇAS içeriğinin kademeli olarak arıtma tesisi deşarj suyu (AD) ile seyreltilerek işletilen reaktörlerde ulaşılan arıtım verimleri kimyasal oksijen ihtiyacı (KOİ) için $\% 87,9$, toplam organik karbon (TOK) için \%86,6 ve inorganik karbon (IK) için \%84,6 olmuştur. Bununla birlikte atıksu muhtevasındaki fosfatın $\left(\mathrm{PO}_{4}{ }^{3-}-\mathrm{P}\right) \% 84$ 'ü ve toplam azotun (TA) \%100'ü giderilmiştir. Diğer taraftan bakteri ve mikroalg kültürlerinin ayrı ayrı kullanılmasının karşılaştırıldığı deneylerde mikroalglerin, atıksu arıtımında bakterilerden daha iyi bir arıtım sağladığı ancak her iki mikroorganizma topluluğunun birlikte kullanılmasının çok daha etkin bir arıtım sağladığı tespit edilmiştir. Çalışma sonunda Türkiye Su Kirliliği Kontrolü Yönetmeliği Evsel Nitelikli Atık Suların Alıcı Ortam Deşarj Standartlarına (Sınıf: 3) uygun düzeyde arıtım sağlanmıştır.
\end{abstract}

Anahtar Kelimeler: Mikroalg, Anaerobik Çürütücü, Atıksu Arıtımı

\section{Treatment of Anaerobic Digestion Effluent in Microalgal Bioreactors}

\begin{abstract}
This study was performed to investigate the effect of combined and separate use of bacteria and microalgae cultures on the efficiency of the treatment domestic anaerobic digestion (AD) effluent to meet the domestic wastewater discharge standards. AD effluent was diluted with waste water treatment plant discharge in different proportions in separate reactors and the treatment efficiency of reactors was compared regarding nutrient removal yields. The highest treatment efficiency was obtained with combined use of bacteria and microalgae cultures and corresponding removal efficiencies were $87.9 \%$ for COD, $86.6 \%$ for TOC, $84.6 \%$ for IC, $84 \%$ for orthophosphates and for $100 \%$ total nitrogen. On the other hand, it was found that although the treatment efficiencies in the reactors including only microalgae cultures are higher than those including only bacterial cultures, and the combined use of microalgal and bacteria cultures still has the highest treatment efficiency among others at the end of the study, AD effluent was successfully treated according the Turkey Water Pollution Control Regulation Domestic Wastewater Discharge Standards (Class:3).
\end{abstract}

Keywords: Microalgae, Anaerobic Digestion, Wastewater Treatment

\section{GíRİş}

Tarımsal atıklar ve arıtma çamurları gibi organik içeriği fazla olan atıkların mikroorganizmalar tarafından oksijensiz ortamda parçalanmasına dayanan anaerobik çürütme prosesi sonrasında, yüksek konsantrasyonlarda azot, fosfor ve kimyasal oksijen ihtiyac1 (KOİ) içeriğine sahip, arıtılması güç bir atıksu oluşmaktadır. Anaerobik çürütücü atıksuyu (AÇAS)

\footnotetext{
* Gebze Teknik Üniversitesi Mühendislik Fakültesi Malzeme Bilimi Mühendisliği Bölümü 41400 Kocaeli İletişim Yazarı: Ülker Diler KERİş ŞEN (udkeris@gtu.edu.tr)
} 
olarak adlandırılan bu tür atıksuların arıtılmasında farklı yöntemler kullanılmakta ve bu yöntemlerin birbirine göre çeşitli dezavantajları bulunmaktadır. Örneğin, AÇAS'ın anaerobik amonyum oksidasyonu (ANAMMOX) yöntemine göre arıtımı sırasında karşılaşılan en büyük problem atıksu muhtevasındaki organik karbonun bu sistemi inhibe etmesidir. AÇAS arıtımında kullanılabilen bir diğer arıtım yöntemi ise bir membran teknolojisi olan, ters ozmos yöntemidir. Bu yöntemle yüksek arıtım verimliliğine ulaş1lırken, sistemden çıkan konsantre atıksu arıtılması daha güç bir su haline gelmekte ve ayrıca atıksu içindeki düşük konsantrasyondaki katı maddeler bile membran tıkanmasına neden olabilmektedir (Vaneeckhaute ve diğ., 2012). Yine geleneksel yöntemler arasında yer alan amonyak sıyırma prosesi yüksek sıcaklık ve pH gerektirmekte ve KOİ giderimi üzerinde belirgin bir etkisi bulunmamaktadır. Bu yöntemlere nazaran mikroalg tabanlı atıksu arıtımın uygulanması daha çevreci ve uygulanabilir bir yaklaşım olmakla beraber atıksu arıtımı sonrası katma değeri yüksek bir ürün elde edilebilmektedir.

1960'lı y1llara dayanan mikroalg tabanlı atıksu arıtım teknolojilerinin, günümüzde yeniden ilgi görmeye başlamasının en büyük nedenleri arasında bu mikroorganizmaların üçüncü nesil biyoyakıt hammaddesi olarak ele alınmaya başlanması olmuştur. Mikroalg türü ve yetiştirilme koşullarına bağlı olarak biyo-molekül (lipit, karbonhidrat, protein ve pigment) sentezinin değiştiği, bazı mikroalg türlerinin lipit sentezlemeyi tercih ederken bazılarının ise karbonhidrat sentezini arttırdığı bilinmektedir (Gürol ve diğ., 2013; Keriş-Şen, 2016). Steril şartlar altında yetiştirilen mikroalglerin insan ek besini, hayvan yemi gibi spesifik kullanım alanlarının bulunmasının yanı sıra yetiştirilmesinde sterilizasyonun gözetilmediği koşulların kullanılmasıyla bu canlıları biyoyakıt hammaddesi olarak ele alınmasını sağlamaktadır. $\mathrm{Bu}$ bağlamda mikroalgal biyokütlenin yetiştirilmesinde atıksu kullanılması bu canlıların yetiştirilmesi için gerekli makro elementler olan karbon, azot ve fosforun ekonomik olarak sağlanması anlamına gelmektedir. Bu doğrultuda şimdiye değin, atıksu muhtevasındaki besi maddelerinin kullanılarak mikroalg yetiştirilmesine odaklanan pek çok çalışma gerçekleştirilmiştir. Çalışmalarda; evsel atıksu arıtma tesisi birincil çıkış suyu (Sydney ve diğ., 2011), biyolojik atıksu arıtma tesisi giriş ve çıkış suyu (Kong ve diğ., 2010), zirai kaynaklı atıksular (Pittman ve diğ., 2011) ve kirlilik yükü fazla olan anaerobik çürütme sonrası oluşan atıksular (Wang ve diğ., 2010; Hajar ve diğ., 2016; Yang ve di ̆.g., 2017; Hajar ve diğ., 2017) gibi çeşitli atıksu kaynakları kullanılmıştır.

AÇAS'ın mikroalgal biyokütle üretimi gerekli olan tüm makro elementlerin yanı sıra içerdiği iz elementler de göz önüne alındığında oldukça elverişli ve ekonomik bir kaynak olduğu düşünülmektedir. Ancak, AÇAS içeriğindeki yüksek amonyum azotunun (NH4+-N) amonyak zehirlenmesine (Park et al. 2010), içerdiği yerel bakterilerin ise biyolojik kirlenmeye neden olabileceği belirtilmektedir (Uggetti ve diğ., 2014). Ayrıca yüksek bulanıklık, yetersiz azot/fosfor (A/F) oranı ve yetersiz KOİ giderimi gibi sorunlarla karşılaşıldığ 1 daha önce gerçekleştirilen çalışmalarda raporlanmıştır (Singh ve diğ., 2011; Wang ve diğ., 2010; Cai ve diğ., 2013(a); Ji ve diğ., 2014; Cheng ve diğ., 2015).

Ugetti ve dĭg. (2014) AÇAS içeriğindeki başlangıç NH4+-N konsantrasyonun kademeli olarak artırıldığı, mikroalgal büyümeyi 7 gün süreyle takip ettiği çalışmasında, başlangıç NH4+$\mathrm{N}$ konsantrasyonunun $50 \mathrm{mg} / \mathrm{L}$ den $185 \mathrm{mg} / \mathrm{L}$ çıkarılmasıyla büyüme hızının $\% 18$ oranında, $185 \mathrm{mg} / \mathrm{L}$ den $260 \mathrm{mg} / \mathrm{L}$ çıkarılmasıyla da büyüme hızının $\% 77$ oranında azaldığını raporlamıştır. Ayrıca çalışmada, başlangıç azot konsantrasyonunun azaltılması için uygulanan seyreltme işleminin ortamdaki diğer besin maddelerinin de konsantrasyonlarının düşmesine neden olduğu böylelikle mikroalgal üremenin kontrol deneylerine nazaran yavaşladığı da belirtmektedir (Uggetti ve diğ., 2014). Başka bir çalışmada ham AÇAS kullanılmış ve yüksek karbondioksit (CO2) içeren (\%9-15) gaz karışımları sisteme verilerek sistemin düşük pH şartlarında $(6-6,5)$ çalıştırılması sağlandığında, serbest amonyak azotundan kaynaklanan toksik etkinin azaldığ 1 ve yüksek miktarda besleyici içeren ham atıksuda yetiştirilen mikroalg kültürlerinin daha yüksek biyokütle konsantrasyonlarına (2-4,8 g/L) ulaşabildiği raporlanmıştır (Cheng ve diğ., 2015). 
Ancak sistem pH'sını istenilen düzeyde tutabilmek için kullanılması gerekli olan CO2 gazının işletmeye büyük bir ek maliyet olarak geri dönmesi söz konusudur.

AÇAS muhtevasında bulunan yerel bakterilerin mikroalg büyüme üzerinde hem pozitif hem de negatif etkisinin bulunduğu belirtilmektedir (Uggetti ve diğ., 2014). Ortamdaki bakteriler tarafından gerçekleştirilen oksijenli solunum sırasında üretilen $\mathrm{CO} 2$ mikroalgler için inorganik karbon (IK) sağlarken, mikroalgler tarafından gerçekleştirilen fotosentez sonucu oluşan fazla oksijen yine bakteriler tarafindan tüketilerek mikroalgleri etkileyen oksidatif stresin azaltabilmesi söz konusudur. Ayrıca hücre dışı madde üretimi fazla olan filamentli bakterilerin sağlayacağı biyoflokülasyon etkisi, mikroalg biyokütlesinin sudan uzaklaştırılmasını kolaylaştırmaktadır. Ortamda bakteri popülasyonunun baskın olması durumunda sistemde üretilen ve yakıt amaciyla kullanılması planlanan biyokütlenin lipit ve karbonhidrat oranı azalmakta, bu da yakıt kalitesini düşürmektedir (Wang ve diğ., 2013). Biyolojik kirlenmeyi önlemek amacıyla literatürde yer alan bazı çalışmalarda atıksu sterilizasyona tabi tutulmuştur (Xu ve di ̌̆., 2015; Cheng ve diğ., 2015). Ancak bu yöntemin atıksu gibi karmaşık bir ortam ve büyük ölçekli uygulamada ne derecede başarılı olacağı şüphelidir. Biyolojik kirlenmeyi tamamen engellemek yerine, çevre şartlarını (1şık, sıcaklık, $\mathrm{pH}, \mathrm{vb}$.) veya işletme şartlarını (hidrolik bekleme süresi, besin takviyesi, vb.) kontrol ederek büyüme ortamını istenilen mikroalg türünün veya türlerinin tercih edeceği ortam haline getirmek daha uygulanabilir bir yöntem olarak görülmektedir.

Ayrıca bilindiği üzere mikroalg büyümesinde en önemli faktörlerden biri de kültür ortamının 1şık geçirgenliğidir. AÇAS'ın sahip olduğu yüksek bulanıklık, özellikle çoğalmak için fotosentez yapan ve bunun için 1şığa ihtiyaç duyan ototrofik mikroalgler için aşılması gereken başlıca engeldir. AÇAS'a genellikle bir ön anıtım uygulanması gerektiği ve bu amaçla filtrasyon, santrifüj ve kimyasal çöktürme gibi çeşitli ön artımı yöntemlerinin kullanıldığı belirtilmektedir (Li ve diğ., 2011; Hajar ve diğ., 2016). Ancak çoğu araştırmacı bulanıklık etkisini azaltmak için ham AÇAS'nu seyrelterek aşmayı denemiştir (Singh ve diğ., 2011; Xu ve diğ., 2015). Işık geçirgenliğinin mikroalgal büyüme üzerine etkisi inceleyen çalışmalarda 30$420 \mu \mathrm{mol} / \mathrm{s} . \mathrm{m} 2$ 1ş1k yoğunlukları kullanılmakla birlikte (Bouterfas et al. 2002; Uggetti ve diğ., 2014) ve bu konu ile ilgili olarak daha önce tarafımızca gerçekleştirilen çalışmalarda 150 $\mu \mathrm{mol} / \mathrm{s} . \mathrm{m}^{2}$ 1şık yoğunluğunun mikroalg büyümesi için optimum değer olduğu tespit edilmiştir (Gürol ve diğ., 2013).

Literatürde yer alan çalışmalar incelendiğinde yüksek azot, fosfor ve KOİ içeren anaerobik çürütücü atık suyunun klasikleşmiş yöntemler yanı sıra mikroalg tabanlı sistemler kullanılarak arıtılmasında netleşmemiş noktaların bulunduğu görülmektedir. $\mathrm{Bu}$ bağlamda AÇAS'ın mikroalgal biyokütle kullanılarak minimum maliyetle evsel atıksu deşarj kriterlerine göre arıtılması ve bu sırada katma değeri yüksek bir ürün olarak mikroalg biyokütlesi elde edilmesi için gerekli koşulların belirlenmesi bu çalışmanın amacını oluşturmaktadır. Bu doğrultuda gerçekleştirdiğimiz çalışma iki bölümden oluşmaktadır. Birinci bölümde, bakteri ve mikroalg kültürlerinin birlikte kullanıldığı ham AÇAS'ın belirlenen oranlarda arıtma tesisi deşarj suyu (AD) kullanılarak seyreltildiği arıtım çalışmaları yer alırken ikinci bölümde ise atıksudaki yerel bakterilerin göstereceği faaliyet sonucu oluşan arıtımın ve atıksu sterilizasyonu yapıldıktan sonra mikrolag ekimi yapılarak sadece mikroalg kültürünün sağlayacağ 1 atıksu arıtım etkisinin incelenmesi yer almaktadir. 


\section{MATERYAL ve METOT}

\subsection{Atıksu Karakterizasyonu}

Çalışma kapsamında kullanılan AÇAS'ın genel karakteri Tablo 1'de verilmiştir.

Tablo 1. Anaerobik çürütücü atıksuyu genel karakteri

\begin{tabular}{|l|c|}
\hline Parametre & Değer \\
\hline $\mathrm{pH}$ & 7,8 \\
\hline Kimyasal Oksijen İhtiyac1 (KOİ) $(\mathrm{mg} / \mathrm{L})$ & 1270 \\
\hline Toplam İnorganik Karbon (TİK) $(\mathrm{mg} / \mathrm{L})$ & 630 \\
\hline Toplam Azot $(\mathrm{TA})(\mathrm{mg} / \mathrm{L})$ & 600 \\
\hline Ortofosfat $\left(\mathrm{PO}_{4}{ }^{3-}-\mathrm{P}\right)(\mathrm{mg} / \mathrm{L})$ & 30 \\
\hline Alkalinite $(\mathrm{mg} / \mathrm{L})$ & 3600 \\
\hline
\end{tabular}

\subsection{Biyokütle Takibi ve Fizikokimyasal analizler}

Biyokütle konsantrasyonuna bağlı optik yoğunluk değişimlerinin belirlenmesi amacıyla öncelikle belli bir konsantrasyona ulaşan mikroalg kültüründen alınan $100 \mathrm{~mL}$ örnek ikiye ayrılmış, 50 mL'si kullanılarak AKM (APHA, 2005) analizi ve diğer $50 \mathrm{~mL}$ örnek, artan oranlarda saf su kullanılarak seyreltilmiş ve 680nm'de Thermo Scientific Genesys 5000 marka spektrofotometrede optik yoğunluk (OD) değişimleri kaydedilmiştir. Her iki analiz arasında bir korelasyon grafiği oluşturulmuş ve biyokütlenin günlük olarak artışı OD680nm analiziyle takip edilmiştir. Atıksu arıtımının takibi amacıyla deneysel çalışmalar boyunca günlük olarak KOİ, İK, toplam organik karbon (TOK), TA, fosfat $\left(\mathrm{PO}_{4}{ }^{3-}-\mathrm{P}\right)$ analizleri yapılmış yine günlük olarak $\mathrm{pH}$ ve sicaklık takibi gerçekleştirilmiştir. IKK, TOK ve TA analizleri IL 550 TOK-TA (Marka) cihazı ile gerçekleştirilirken, KOİ ve fosfat analizlerinde sırasıyla Standart method 5220-C ve 4500-P-C kullanılmıştır (APHA, 2005). İşletilen sistemlerde ki pH ve sıcaklık takibi bir multiparameter ölçer (Metler Toledo) kullanılarak sağlanmıştır.

\subsection{Mikroalglerin Ön Aklimasyonu}

Aklimasyon deneyleri için $750 \mathrm{~mL}$ hacme sahip cam reaktörlerin kullanıldı ̆̆ aydınlanmanın yüzeyden, gün ışığı spektrumuna sahip floresan lambalar kullanılarak sağlandığı ve reaktörlerdeki karışımın ise reaktör tabanına yerleştirilen difüzörlerden hava verilmesiyle elde edildiği deney düzenekleri hazırlanmıştır. Deneysel çalışmalarda kullanılan karışık mikroalg kültürü önceki çalışmalarımızda (Keriş-Şen ve diğ., 2014; Keriş-Şen ve diğ., 2017) kullandığımız ve laboratuvar şartlarında BG11 (Ripka ve diğ.,1979) sentetik besi ortamına ekilerek yetiştirilen kültürdür. Reaktör 12 saat aydınlık ve 12 saat karanlık olacak şekilde 150 $\mu \mathrm{mol} / \mathrm{s} . \mathrm{m}^{2}$ 1şık yoğunluğunda çalıştırılmış ve mikroalglerin ön kültüvasyonu (ortam şartlarına adaptasyonu) sağlanmıştır. Reaktör içerisinde baskın olarak Chlorophyceae sınıfı, Chlorococcales takımında yer alan Scenedesmus sp., Chlorococcum sp türlerinin baskın olduğu yapılan Carl Zeiss Marka, Dijital kamera ataçmanlı, Axio Scope Trinoküler Faz-Kontrast Mikroskop kullanılarak 100 kat büyütmede yapılan mikroskobik gözlemlerle tespit edilmiştir.

Ön aklimasyonu BG11 besi ortamında sağlanan karışık mikroalg kültüründen alınan $50 \mathrm{~mL}$ örnek, $500 \mathrm{~mL}$ hacmimde 5:95 oranında arıtma tesisi deşarj atıksuyu (AD) ile seyreltilen anaerobik çürütücü çıkış suyuna ekilmiştir. Mikroalglerin atıksuya aklimasyon deneyleri, ön aklimasyon deneylerinde kullanılan düzeneklerde gerçekleştirilmiş yedi gün sürelik inkübasyon sonunda aş1 kültürü elde edilmiştir. 


\subsection{Deneysel Çalıșmalar}

\subsubsection{Bakteri-Mikroalg faunasının birlikte kullanıldığı deneyler}

Bakteri-mikroalg karışık kültürünün ortak etkisinin tanımlanması amacıyla başlatılan bu ilk deney seti, yerel bakteri içeriği bulunan atıksuya $50 \mathrm{~mL}$ mikroalg aşı kültürü ilavesi yapılarak gerçekleştirilmiştir. Çalışmada, literatürden ve daha önceki çalışmalardan kazanılan bilgiler 1şı ğında, AÇAS'ın, azalan oranlarda AD ile Tablo 2'de tanımlandığı şekilde seyreltilerek ve seyreltme yapılmadan (\%100 AÇ atıksuyu) deney düzeneklerine alınmış ve her set kontrol reaktörleriyle birlikte işletilerek, mikroalgal büyüme ve atıksu arıtımı takip edilmiştir. Yaklaşık 20 gün süreyle devam eden deneysel çalışma boyunca buharlaşma nedeniyle sistemden eksilen su kadar reaktöre saf su ilave edilerek toplam hacmin $500 \mathrm{~mL}$ de sabit tutulması sağlanmıştır. Buharlaşan su miktarınca atıksu eklenmemesinin nedeni ortama ilave besi takviyesinin sağlanmamasıdır. Tablo 2. Deneysel kurulum ve adlandırma gösterilmektedir.

Tablo 2. Bakteri-mikroalg kültürlerinin birlikte kullanıldığı deney setinin kurulumu

\begin{tabular}{|c|c|c|}
\hline Reaktör ad1 & AÇAS (\%) & AD (\%) \\
\hline R1 & 10 & 90 \\
\hline R2 & 25 & 75 \\
\hline R3 & 50 & 50 \\
\hline R4 & 75 & 25 \\
\hline R5 & 100 & - \\
\hline
\end{tabular}

\subsubsection{Mikroalg ve Bakterilerin Bireysel Etkilerinin İncelenmesi}

Bakteri ve mikroalglerin atıksu arıtımı üzerindeki etkilerinin ayrı ayrı belirlenmesi amacıyla yürütülen bu çalışmalarda, bakteriyel faaliyetin atıksu arıtımı üzerindeki bireysel etkisinin incelenmesi için, \%75AÇAS-\%25AD oranında atıksu içeren reaktör (OX) içerisine sadece hava verilerek bakteriyel faaliyetin devam etmesi sağlanmış ve atıksu arıtımı takip edilmiştir.

Sadece mikroalglerden kaynaklı atıksu arıtımının tanımlanması amacıyla yürütülen deneysel çalışmada ise AÇAS ve AD kaba filtre kâğıdı kullanılarak süzülmüş ve süzüntü $121^{\circ} \mathrm{C}$ 'de 15 dakika süreyle otoklavlanarak sterilizasyona tabi tutulmuştur. Sterilizasyon sonras 1 toplam hacim $500 \mathrm{~mL}$ olacak şekilde AÇAS ve AD Tablo3'de tanımlandığı şekilde karıştırılmış ve her bir reaktöre $50 \mathrm{~mL}$ aşı kültürü (15 mg mikroalgal biyokütle/L) eklenerek deneysel çalışmalar kontrol reaktörleri ile birlikte işletilmeye alınmıştır (M1-3).

Tablo3. Bakteri ve mikroalg ayrı ayrı kullanıldığı deney setinin kurulumu

\begin{tabular}{|c|c|c|}
\hline Reaktör ad1 & AÇAS (\%) & AD (\%) \\
\hline M1 & 50 & 50 \\
\hline M2 & 75 & 25 \\
\hline M3 & 100 & - \\
\hline OX & 75 & 25 \\
\hline
\end{tabular}




\section{BULGULAR ve TARTIȘMA}

\subsection{Mikroalgal büyüme}

Bakteri ve mikroalg kültürlerinin birlikte kullanıldığı deney setlerine ait mikroalgal biyokütle üretimi Şekil 1'de gösterilmektedir. Şekil 1'den görüldüğü üzere her ne kadar mikroalglerin atıksuya ön aklimasyonu sağlansa da hücrelerin, artan organik madde konsantrasyonuna sahip yeni ortam koşullarına adaptasyonu zaman almıştır. R1 reaktörü için mikroalglerin aklimasyonunu birinci günün sonunda tamamladığı, devamında logaritmik büyüme fazına geçtiği, maksimum biyokütle konsantrasyonun $425 \mathrm{mg} / \mathrm{L}$ ile kültüvasyonun 16 . gününde elde edildiği görülmektedir. R1 reaktörü için özgül büyüme hızı 0,59 gün $^{-1}$ olarak hesaplanmıştır.

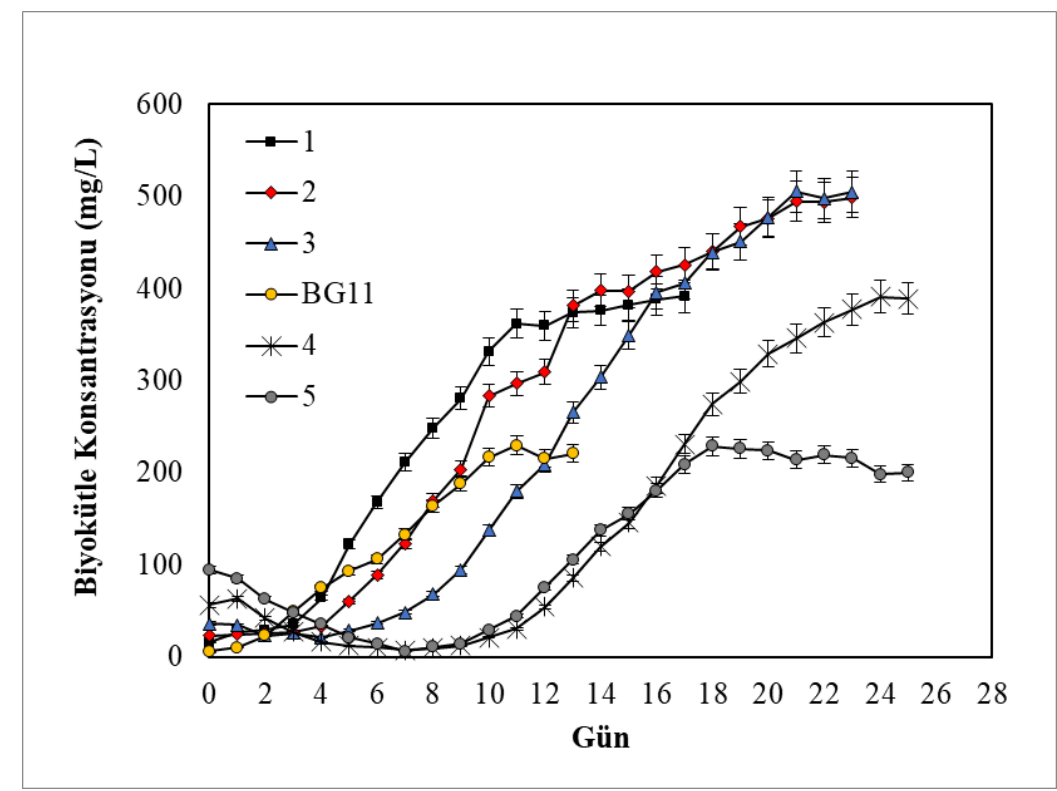

Şekil 1:

R1-R5 ve BG11, reaktörlerine ait mikroalgal üreme (AÇAS:AD 10:90 (R1), 25:75(R2), 50:50(R3), 75:25(R4), \%100 AÇAS(R5)).

R2-R5 reaktörleri AÇAS miktarının ve doğal olarak bulanıklığın arttığı işletim koşullarında mikroalgal büyüme ve atıksu arıtımının incelenmesi amacıyla işletmeye alınan reaktörlerdir. $\mathrm{Bu}$ reaktörlerde bulanıklığın yüksek olması nedeniyle mikroalg ekimi ve ekimin hemen sonrasında okunan optik yoğunluk ölçümlerinde, atıksu muhtevasındaki kolloidal maddeler ve bakteriler nedeniyle olduğu düşünülen, benzer 1şık absorbsiyonu meydana gelmiştir. Biyokütle miktarının tespit edilmesi amacıyla günlük olarak yapılan optik yoğunluk okumalarının, bu reaktörlerden R2 ve R3 için ilk dört gün, R4 ve R5 için ilk yedi günlük süre boyunca azaldığı tespit edilmiştir. Her ne kadar hem reaktör içine atmosferik hava verilerek hem de reaktör tabanından karıştırılarak reaktör içinde tam karışımın sağlanması amaçlansa da atıksu içeriğindeki kolloidal maddelerin zaman içerisinde flok oluşturarak reaktör tabanındaki ölü noktalara çöktüğü gözlenmiştir. Kolloidal maddelerin bu şekilde çökelmesi ile birlikte reaktörlerin berraklaştığ 1 ve devamında mikroalgal büyüme ile optik yoğunluğun arttığ1 gözlenmiştir. R2 ve R3 reaktörlerinde kültüvasyonun 5. günü itibariyle logaritmik büyüme fazına geçilmiştir. R2 reaktörü en fazla biyokütle yetiştirilmesinin sağlandığı reaktör olup maksimum biyokütle konsantrasyonu yaklaşık olarak $530 \mathrm{mg} / \mathrm{L}$ ve özgül büyüme hızı 0,54 gün $^{-1}$ olarak hesaplanmıştır. Reaktör içerisinde AÇAS içeriğinin yani zor parçalanır madde miktarının artmasına bağl1 olarak mikroalg büyümesinin yavaşladığı $\left(0,29\right.$ gün $\left.^{-1}\right)$ tespit edilmiştir. R3 
reaktöründe maksimum biyokütle konsantrasyonuna $500 \mathrm{mg} / \mathrm{L}$ ile kültüvasyonun sonunda ulaşılırken R4 ve R5 reaktörleri için maksimum biyokütle konsantrasyonu sırasıyla 390 ve $200 \mathrm{mg} / \mathrm{L}$ ile sınırlanmıştır. Kontrol reaktörü olarak işletilen BG11 besi ortamında yetiştirilen mikroalg kültürüne ait özgül büyüme hız1 0,52 gün $^{-1}$ olarak tespit edilmiştir. R1 ve R2 reaktörleri ile kontrol reaktöründe benzer özgül büyüme hızları elde edilmesi, seçilen AÇASAD karışım oranlarının, mikroalgal büyüme için elverişli oranlarda olduğunu göstermektedir. Yine R2 reaktöründe AÇAS seyrelmesinin daha az olduğu göz önüne alınarak bu seyrelme oranının mikroalgal büyüme için en elverişli ortam olduğu sonucuna varılmıştır düşünülmektedir. R4-R5 reaktörlerindeki mikroalgal büyüme hızının düşmesine ortamdaki yüksek konsantrasyondaki amonyum azotunun neden olduğu düşünülmektedir. Bu çalışmaya benzer bir şekilde gerçekleştirilen bir çalışmada, mikroalgal büyüme iki hafta süreyle takip edilmiş ve başlangıç $\mathrm{NH}_{4}{ }^{+}-\mathrm{N}$ konsantrasyonu $100-1000 \quad \mathrm{mgNH}_{4}{ }^{+}-\mathrm{N} / \mathrm{L}$ aralığında değiştirilmesinin üretilen biyokütle üzerindeki etkileri araştırılmıştır (Park et al. 2010). Çalışmada $100 \mathrm{mgNH}_{4}{ }^{+}$-N/L konsantrasyonu ile maksimum üreme (800mgbiyokütle/L) elde edilirken, $\mathrm{NH}_{4}{ }^{+} \mathrm{N}$ konsantrasyonun $200 \mathrm{mg} / \mathrm{L}$ 'den $500 \mathrm{mg} / \mathrm{L}$ 'ye çımasıyla inhibisyonun meydana geldiği ve üremenin azaldığını belirtmiştir.

Yüksek sıcaklık ve basıncın kullanıldığ sterlizasyon işlemi sonucunda AÇAS suyunun $\mathrm{pH}$ değeri 7,8'den 11,3'e yükselmiş ve bu durum da AÇAS muhtevasındaki toplam azotun büyük bir bölümünün $\mathrm{NH}_{3} \mathrm{~N}$ formunda sistemden hava ile siyırılmasına neden olmuştur. Aynı zamanda atıksu dibinde karbonat çökelekleri meydana gelmiş ve bunun sonucunda AÇAS içeriğindeki çözünmüş formdaki inorganik karbon konsantrasyonları da düşmüştür. Ayrıca beklenilenin aksine sterilizasyon sonrası atıksu bulanıklığında büyük ölçüde artış meydana gelmiştir. Sterilizasyon sonrası AÇAS'nun genel karakterizasyonu Tablo 4'te özetlenmiştir.

Tablo4. Sterilizasyon sonrası AÇAS özellikleri

\begin{tabular}{lc}
\hline \multicolumn{1}{c}{ Parametre } & Değer \\
\hline $\mathrm{pH}$ & $11,3^{*}$ \\
\hline Kimyasal oksijen ihtiyac1 (mg/L) & 400 \\
\hline Toplam organik karbon $(\mathrm{mg} / \mathrm{L})$ & 160 \\
Toplam inorganik karbon $(\mathrm{mg} / \mathrm{L})$ & 360 \\
Toplam azot $(\mathrm{mg} / \mathrm{L})$ & 390 \\
Fosfat fosforu $(\mathrm{mg} / \mathrm{L})$ & 11 \\
Alkalinite $(\mathrm{mg} / \mathrm{L})$ & 2600 \\
\hline *Sterilizasyon sonras1 & \\
\hline
\end{tabular}

AÇAS muhtevasında meydana gelen bu değişimler mikroalgal büyüme üzerinde büyük oranda negatif etkiye neden olmuştur. AÇAS muhtevasındaki yerel bakterilerin mikroalgal büyüme ve atıksu arıtımı üzerindeki etkisinin bertaraf edilmesi amacıyla sterilize edildikten sonra işletilmeye alınan M1-M3 reaktörlerine ait büyüme grafikleri Şekil 2'de gösterilmektedir. 


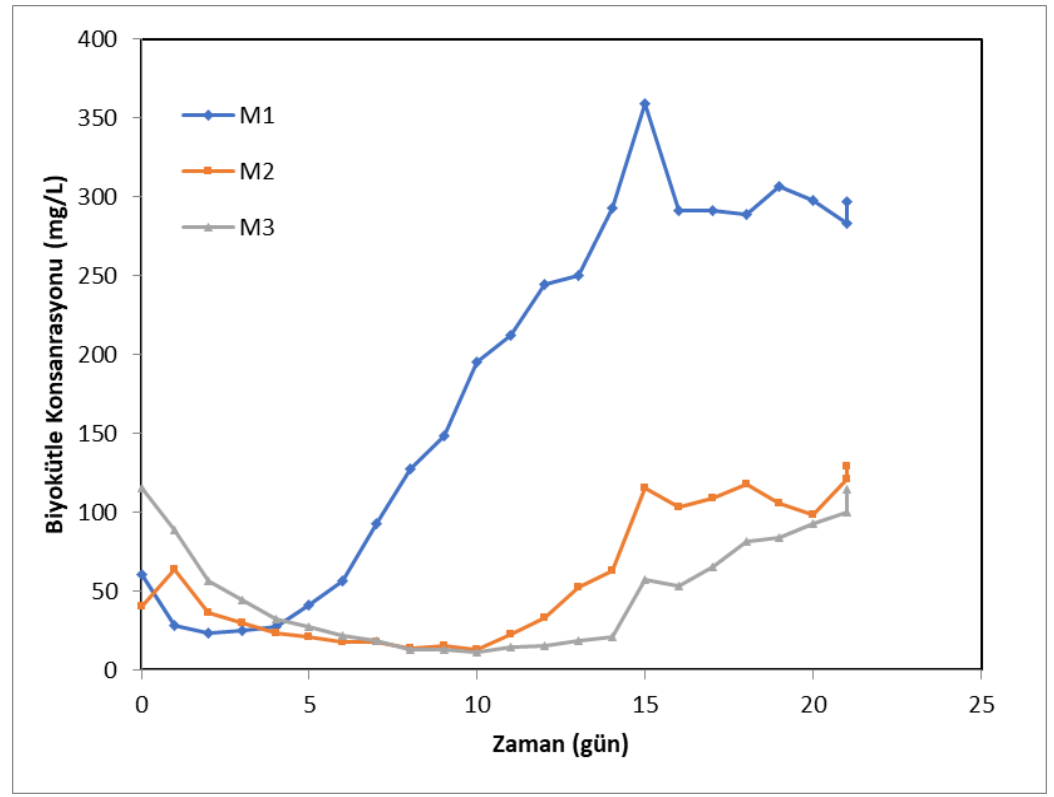

Şekil 2:

M1, M2, M3, reaktörlerine ait mikroalgal üreme (steril AÇAS: AD, 50:50(M1), 75:25(M2), $\% 100 A C ̧ A S(M 3))$.

Şekil 2'de görüldüğü gibi başlangıç biyokütle konsantrasyonu $15 \mathrm{mg} / \mathrm{L}$ olan kültürlerde atıksu bulanıklığı nedeniyle çok daha yüksek biyokütle konsantrasyonu değerleri okunmuştur. $\mathrm{Bu}$ durum mikroalgal büyüme amaciyla kullanılan optik yoğunluk okumalarının her zaman sağlıklı sonuç vermeyeceğini göstermektedir. Reaktörlerdeki bulanıklık bir önceki deney setinde olduğu gibi zaman içinde kolloidal maddelerin reaktör tabanındaki ölü noktalara çökelmesiyle azalmıştır. M1 reaktörü AÇAS muhtevasının en az olduğu reaktör olup bu sistemde 3 günlük adaptasyon sonrası mikroalgal büyümenin logaritmik faza geçtiği görülmektedir. M1 Reaktöründe maksimum biyokütle konsantrasyonu $360 \mathrm{mg} / \mathrm{L}$ ve özgül büyüme hızı 0,39 gün $^{-1}$ olarak tespit edilmiştir. Bu değer atıksuyun sterilizasyonu yapılmadan kullanılan deney setine nazaran 1,3 kat daha düşüktür. Bu duruma sterilizasyon sonras1 meydana gelen besi miktarlarındaki azalmanın neden olduğu düşünülmektedir. M2 reaktöründe mikroalgal büyüme 10 gün sonunda başlarken M3 reaktörü için 14 gün sürmüştür. Ortamdaki besi maddelerinin hızla tükenmesi sonucunda M2 reaktöründe maksimum $150 \mathrm{mg} / \mathrm{L}$, M3 reaktöründe ise $100 \mathrm{mg} / \mathrm{L}$ biyokütle konsantrasyonuna ulaşılmıştır.

Büyük ölçekli bir mikroalgal atıksu arıtımı planlandığında, atıksuyun sterilizasyonun mümkün bir yaklaşım olarak ele alınamayacağı bilinmekle birlikte bu deney seti bakterilerden arındırılmış ve yüksek konsantrasyonlarda karbon ve azot içeren bir suyun mikroalgal biyokütle ile arıtılması durumunu incelenmesi amacıyla gerçekleştirilmiştir. AÇAS'ın sterilizasyonu beklenilenin aksine mikroalg büyümesinde olumsuz bir etkiye neden olmuş, mikroalgal biyokütlenin atıksu arıtımı üzerindeki etkisi belirlenememiştir. Literatürde yer alan AÇAS'nun otoklavlanarak sterilizasyona tabi tutulduğu ve ham olarak kullanımının mikrobiyal üreme üzerindeki etkilerinin incelendiği bir çalışmada, sterilizasyon sonrası atıksu muhtevasındaki toplam azot konsantrasyounun $460 \mathrm{mg} / \mathrm{L}$ 'den $400 \mathrm{mg} / \mathrm{L}$ 'ye düştügü belirtilirken, $\mathrm{pH}$ değerinde ise hiçbir değişikliğin meydana gelmediği ve pH7'de sabit kaldığı raporlanmıştır (Deng et al. 2017). Steril ve steril olmayan AÇAS 2, 3 ve 4 kat seyreltilerek kullanılmış ve 3 kat seyreltilen AÇAS'nun hem steril şartlarda hem de steril olmayan şartlarda mikrobiyal büyüme için en elverişli ortam olduğu belirtilmiştir. Benzer şekilde ham ve sterilize AÇAS kullanılarak mikroalgal büyümenin incelendiği bir başka çalışmada da sterilizasyon sonrası atıksu muhtevasında önemli değişimlerin meydana gelmediği raporlanmıştır (Li ve diğ., 2011). 
Sterilizasyon süresince uygulanan yüksek sıcaklık ve basınç altında neredeyse hiçbir değişimin meydana gelmemesi mümkün olarak görülmemekle birlikte, belirtilen çalışmalarda kullanılan AÇAS muhtevasındaki azot ve karbon formlarının, bu çalışmadaki azot ve karbon formlarından farklı yapılarda bulunması nedeniyle sterilizasyon sonrası bir değişimin tespit edilemediği düşünülmektedir.

\subsection{Atıksu Arıtımının Takibi}

Çalışma boyunca işletilen reaktörlerde mikroalgal büyümenin yanı sıra atıksu arıtım verimliliğinin takip edilmiştir. Bu amaçla her bir reaktör için üç tekrarlı olmak üzere, kimyasal oksijen ihtiyacı (KOI), toplam organik karbon (TOK), inorganik karbon (IK), toplam azot (TA), ortofosfat analizleri günlük olarak yapılmış ve sonuçlar Şekil 3-12'de gösterilmiştir.

Bakteri-mikroalg kültürlerinin birlikte kullanıldığı ve AÇAS miktarının kademeli olarak arttırıldığı deney setindeki KOİ gideriminin zamana bağlı olarak değişimi Şekil 3'de gösterilmektedir.

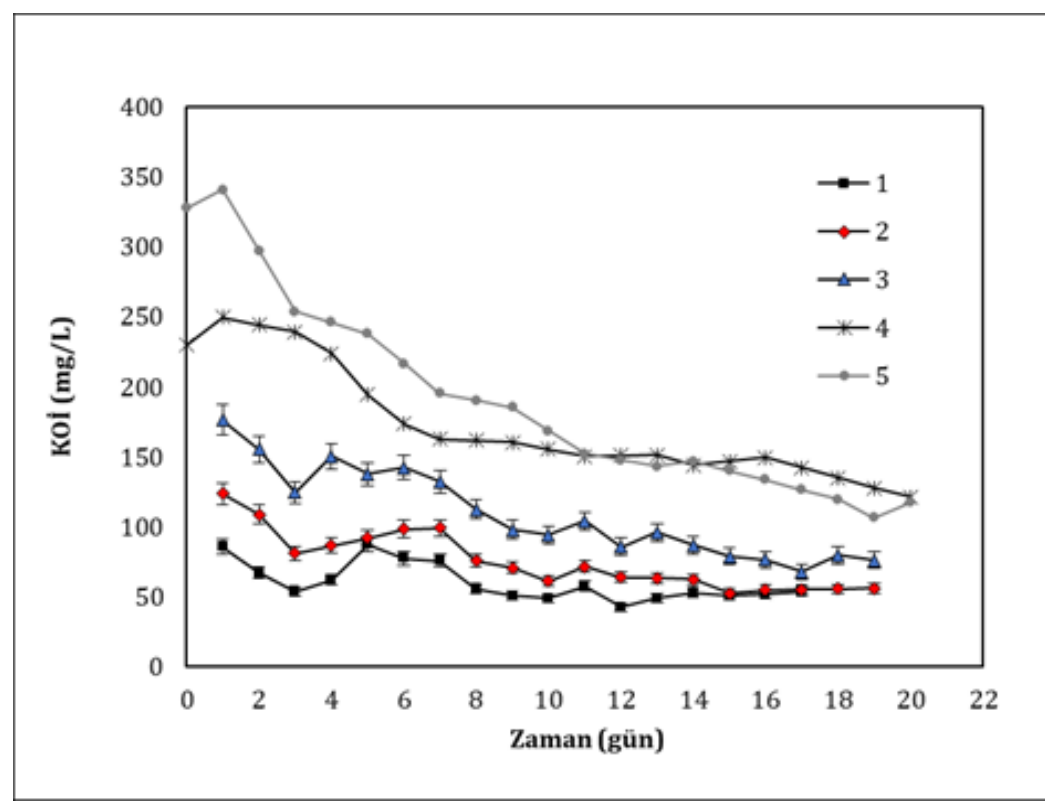

Şekil 3:

R1-R5 reaktörlerine ait KOİ giderimi (AÇAS:AD 10:90 (R1), 25:75(R2), 50:50(R3), 75:25(R4), $\% 100 A C ̧ A S(R 5))$.

Şekil 3 incelendiğinde R1-R3 reaktörleri için ilk gün KOİ giderim verimlerinin oldukça yüksek olduğu görülmektedir. İlk gün giderim verimlerinin R3 reaktöründe \%73,6, R2 reaktöründe $\% 65,1$ ve R1 reaktöründe ise $\% 45,3$ olduğu tespit edilmiştir. Bununla birlikte AÇAS miktarının yüksek olduğu R4 ve R5 reaktörlerindeki giderimin mikroorganizmaların adaptasyon fazını tamamlanmasıyla birlikte hızla KOİ giderimi gerçekleştirdikleri görülmektedir. AÇAS miktarının artmasına bağlı olarak rektörler içindeki biyolojik parçalanmaya direnç gösteren madde miktarının artması sonucunda KOİ giderim verimlerinin düştüğü görülmüş olup, en konsantre AÇAS içeriğine sahip olan R5 reaktöründe \%64,2'lik KOİ giderim verimi tespit edilmiştir. Bununla birlikte AÇAS içeriğinin \%50 oranında tutulduğu R3 reaktöründe en yüksek KOİ giderim verimi kültüvasyon sonunda \%87,9 ve giderim hızı 6,9 $\mathrm{mg} / \mathrm{L}$.gün olarak bulunmuştur.

AÇAS sterilizasyonu yapıldıktan sonra mikroalg ekiminin yapıldığı M1-M3 ve AÇAS içeriğindeki bakterilerin atıksu arıtımı üzerindeki etkisinin takip edildiği kontrol (OX) reaktörlerine ait KOİ gideriminin zamana bağlı olarak değişimi Şekil 4'de gösterilmektedir. Mikroalgal biyokütlenin atıksu arıtımı üzerindeki etkilerini gösteren M1, M2 ve M3 
reaktörlerine ait KOİ giderim verimleri sırasıyla \%68,6, \%64,6, \%54,8 olarak tespit edilirken sadece bakteriyel faaliyetin gerçekleştiği OX reaktöründeki KOİ giderim verimi \%45,7 olarak tespit edilmiştir. Görüldüğü üzere mikroalgal biyokütlenin kullanılması daha yüksek bir giderim sağlamaktadır. Çalışma sonucunda, KOİ giderilmesinde mikroalgal biyokütlenin etkin rol aldığ görülmektedir.

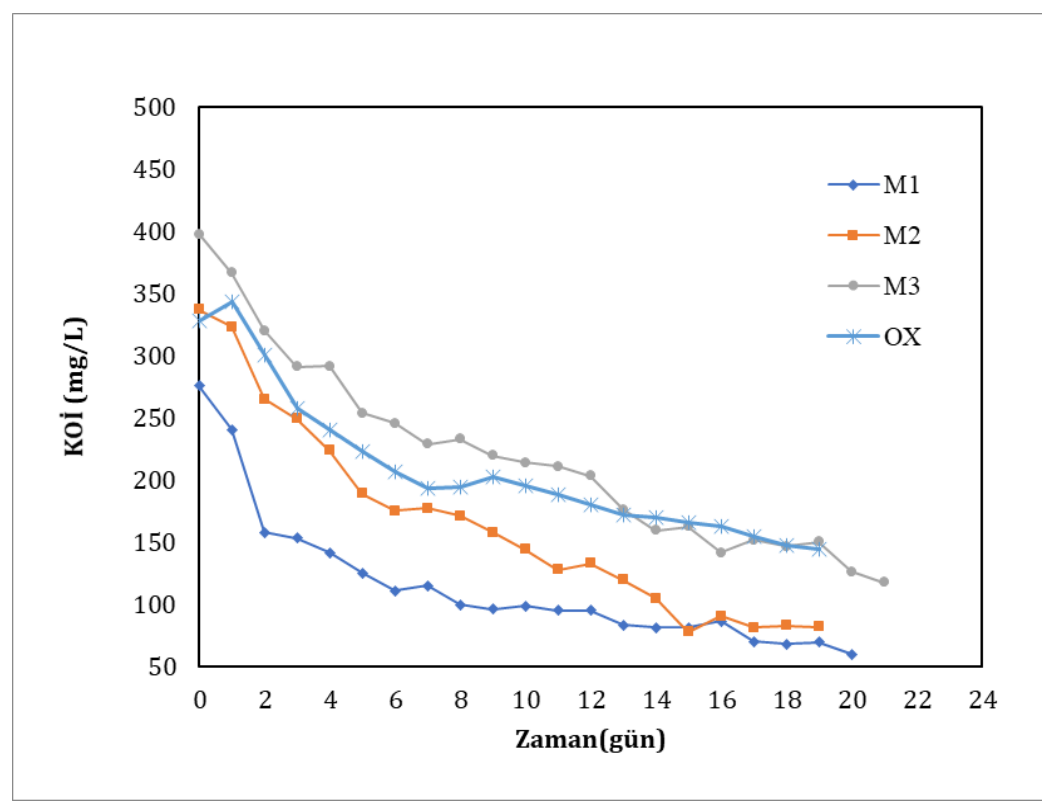

Şekil 4:

M1-M3 ve OX reaktörlerine ait KOI giderim verimleri (steril AÇAS: AD, 50:50(M1), 75:25(M2), \%100 AÇAS (M3), 75:25 ham AÇAS:AD (OX)).

Atıksu arıtımının önemli bir göstergesi olan KOİ değerinin bakteri-mikroalg faunasının birlikte kullanılmasıyla daha etkin bir şekilde giderildiği tespit edilmiştir. Bu durumun bakteri ve mikroalglerin ortak etkisinden kaynaklandığı düşünülmektedir. AÇAS muhtevasında bulunan yerel bakterilerin AÇAS içeriğindeki kompleks organikleri hücre dışı salgıladıkları enzimlerle parçalamaları sonucunda mikroalgal biyokütle tarafından daha kolay metabolize edilen organik yapılar oluşmaktadır (Deng et al. 2017). Kompleks bileşiklere nazaran daha hızlı parçalanabilen bu organik madde içeriğinin mikroalgal büyümede kullanılması sonucunda daha etkin bir atıksu arıtımı sağlanmıştır.

Reaktör içindeki toplam organik karbon giderimi için gerçekleştirilen TOK analizlerine ait veriler Şekil 5'te gösterilmektedir. AÇAS muhtevasının düşük tutulduğu R1-R3 reaktörleri için TOK giderim verimlerinin de KOİ giderim veriminde olduğu gibi ilk gün hızla gerçekleştiği tespit edilmiştir. R1, R2 ve R3 reaktörleri için sırasıyla ilk gün giderim verimlerinin $\% 61,1$, $\% 67,9$ ve $\% 80$ olduğu görülmektedir. Kültüvasyon sonunda R3 reaktöründe toplam TOK giderim verimi \%86,6 ve giderim hızı 11,5 mg/L.gün olarak bulunmuştur. Benzer şekilde R2 reaktöründe toplam TOK giderim verimi \%82,3 olarak tespit edilmiş olup, R1 reaktörü için TOK giderim verimi \%70,8 ile sınırlı kalmıştır. R2 ve R1 reaktörleri için TOK giderim hızları sırasıyla 10,3 ve $4,5 \mathrm{mg} / \mathrm{L}$.gün olarak tespit edilmiştir. Beklenildiği gibi reaktör içeriğindeki dirençli organik madde miktarının arttığı R4 ve R5 reaktörlerinde TOK giderim veriminin azaldığı ve sırasıyla $\% 65$ ve $\% 67,6$ olduğu tespit edilmiştir. 


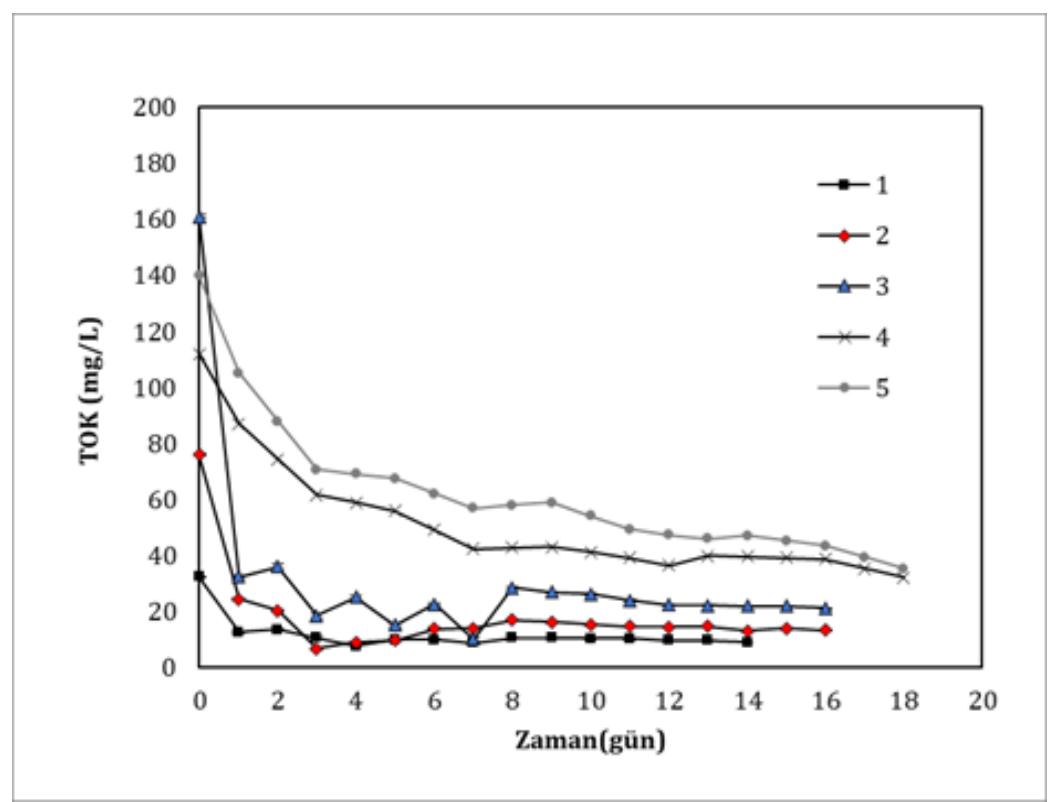

\section{Şekil 5:}

R1-R5 reaktörlerine ait TOK giderimi (AÇAS:AD 10:90 (R1), 25:75(R2), 50:50(R3), 75:25(R4), \%100 AÇAS(R5)).

Mikroalgal biyokütle ve bakterilerin TOK giderimi üzerindeki etkilerinin ayrı ayrı tespit edildiği TOK giderim verimleri Şekil 6'da gösterilmektedir. Toplam organik karbon giderim verimleri de KOİ giderim verimlerinde olduğu gibi bakteri-mikroalg karışık kültürünün birlikte kullanıldığı deney setine nazaran daha düşük seviyelerde kalmıştır. M1-M3 reaktörleri için TOK giderim verimleri sirasıly $\% 75,6, \% 76,9$, ve $\% 70,2$ olarak tespit edilmiştir. Yine sadece bakteriler tarafından gerçekleştirilen TOK giderim veriminin, aynı şartlardaki mikroalgal biyokütlenin kullanıldığ deney setine nazaran daha düşük seviyelerde kaldığ 1 ve $\% 65,8^{\prime}$ lik bir giderimin sağlandığı görülmüştür.

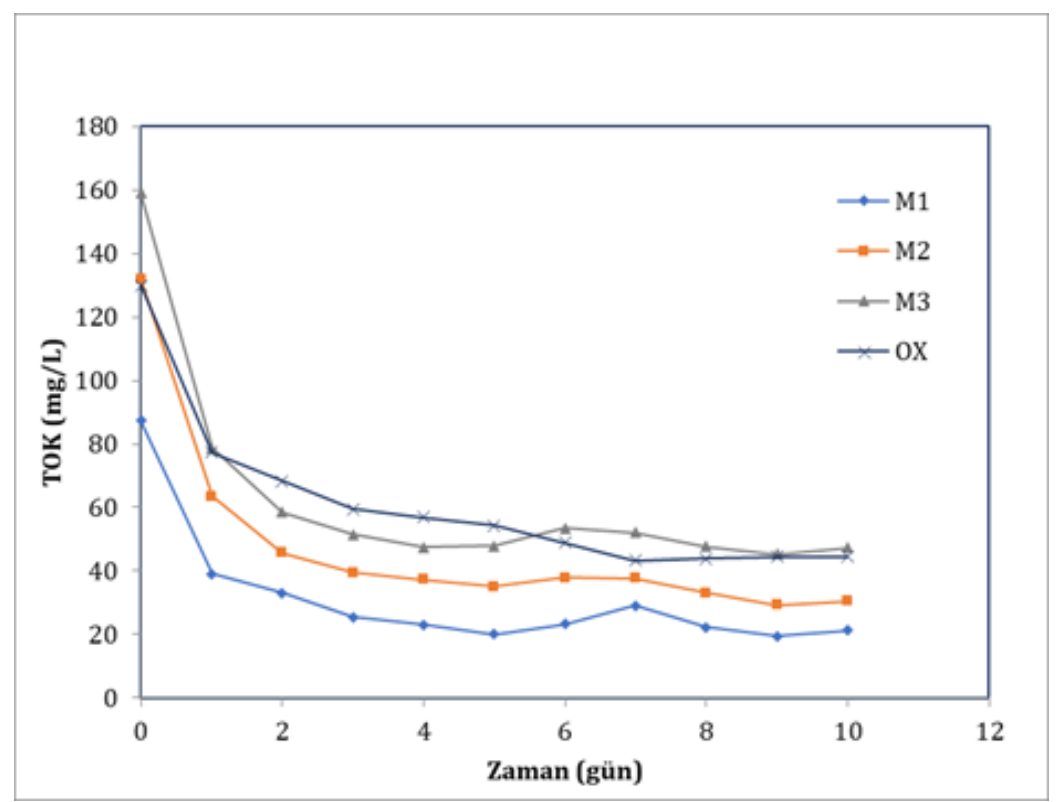

Sekil 6:

M1-M3 ve OX reaktörlerine ait TOK giderim verimleri (steril AÇAS: AD, 50:50(M1), 75:25(M2), \%100 AÇAS (M3), 75:25 ham AÇAS:AD (OX)). 
Her bir reaktör için TOK giderimin yaklaşık olarak 5 gün süreyle devam ettiği ve bu süre sonrasında sabit kaldığı görülmektedir. Giderilemeyen bu organik madde konsantrasyonunun biyolojik parçalanmaya direnç gösteren organik maddelerden kaynaklandığ 1 ve bu maddelerin giderilmesi için ileri oksidasyon yöntemlerinin kullanılması gerektiği görülmektedir.

Reaktör içindeki inorganik karbon değişimlerinin takibi amacıyla gerçekleştirilen İK giderimine ait veriler Şekil 7 ve 8'de gösterilmektedir. Şekil 7'de bakteri-mikroalg kültür karışımının sinerjistik etkisi gösterilirken Şekil 8'de mikroalgal biyokütle ve bakterilerin İK giderimi üzerindeki bireysel etkileri gösterilmektedir.

Reaktör içi tam karışımın sağlanması amacıyla rektör içerisine sürekli olarak atmosferik hava verilmesi ortamdaki İK konsantrasyonunun artmasına neden olacağı ve İK gideriminin sınırlı kalacağı beklense de Şekil 7'de görüldüğü üzere İK giderim verimleri de TOK ve KOİ giderim verimlerinde olduğu gibi oldukça yüksek olarak bulunmuştur. $\mathrm{Bu}$ durum kullanılan karışık mikroalg kültüründe miksotrofik mikroalgler kadar ototrofik mikroalglerin de bulunduğunun ve arıtımda her iki türünde aktif olarak rol aldığının bir göstergesidir. Her ne kadar ortamdaki organik karbon muhtevasının yüksek olması, karışık mikroalg kültüründe miksotrofik türlerin baskın olmasını gerektirse de sonuçlar ototrofik türlerin de besin için hetetrofik türlerle rekabet ettiği ve yaşamsal döngülerini gerçekleştirebildiklerini göstermektedir. Karışık mikroalg kültüründeki bu farklı türdeki mikroalglerin kesin olarak tanımlanması ancak 16S/18S rRNA analizlerinin gerçekleştirilmesi ile mümkün olup, çalışma kapsamında bu tarz bir analiz yapılmamıştır.

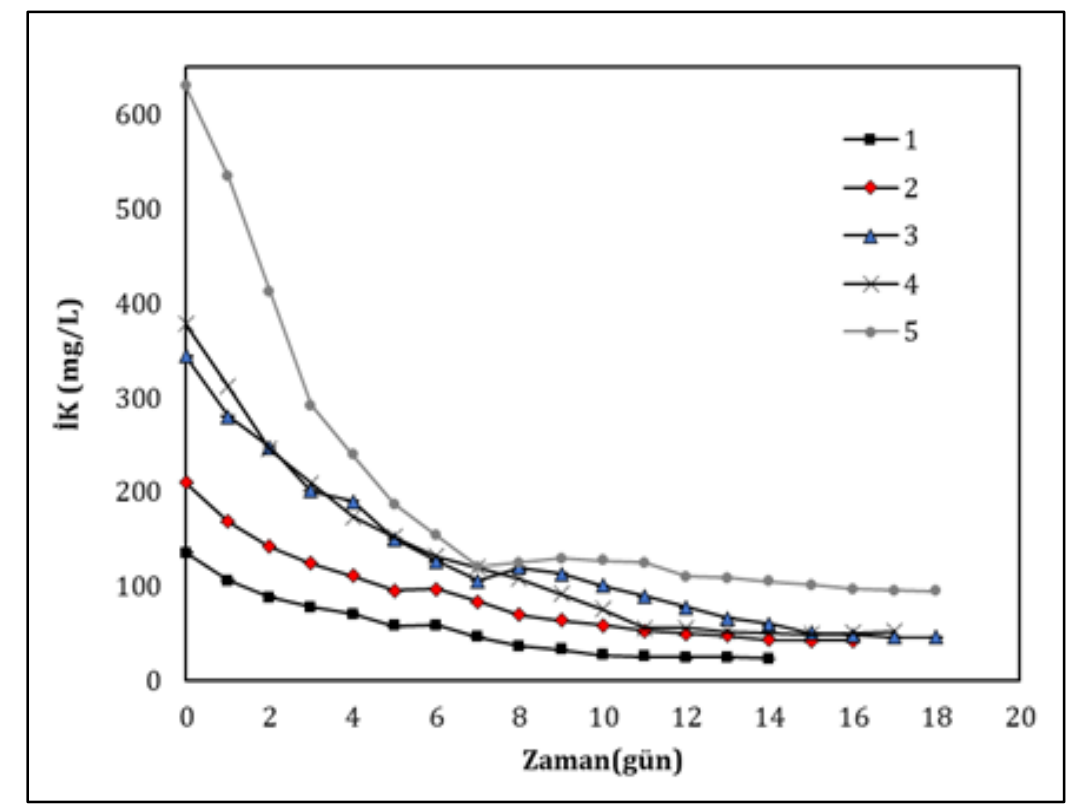

Şekil 7:

R1-R5 reaktörlerine ait IK giderimi (AÇAS:AD 10:90 (R1), 25:75(R2), 50:50(R3), 75:25(R4), $\% 100 A C ̧ A S(R 5))$

Sadece mikroalgal biyokütlenin kullanıldığ1 M1-M3 reaktörlerinde de inorganik karbon gideriminin hızla gerçekleştiği buna nazaran sadece bakteriyel faaliyetin olduğu OX reaktöründe ise İK gideriminin daha düşük seviyelerde kaldığ1 görülmüştür. M1-M3 reaktörleri için IK giderim verimleri sırasıla \%82,7, \%80,3, \%84,5 ve OX reaktörü için \%74,5 olarak tespit edilmiştir. Kültüvasyonun tamamlanmasıyla bakteri-mikroalg faunasının birlikte kullanıldığı deneylerdeki en yüksek İK giderim verimi \%84,6 ile R3 reaktöründe, \%79,8 ile R2 reaktöründe ve \%82 ile R1 reaktöründe elde edilmiştir. 


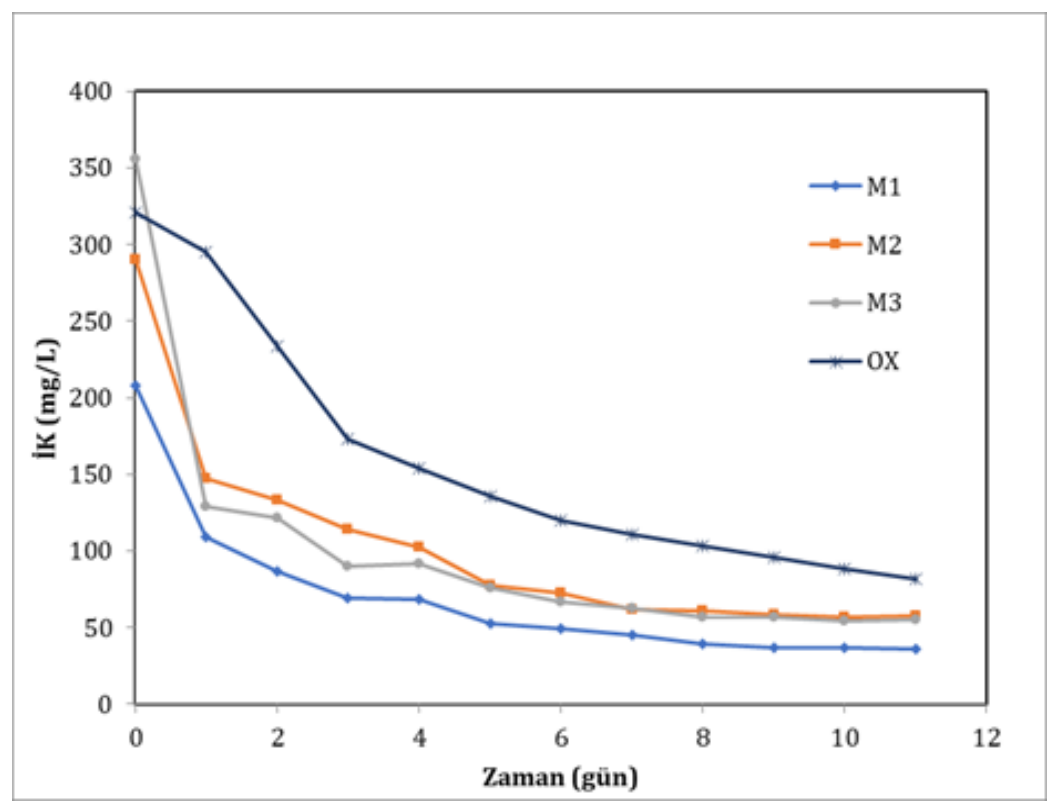

Şekil 8:

M1-M3 ve OX reaktörlerine ait IK giderim verimleri (steril AÇAS: AD, 50:50(M1), 75:25(M2), $\% 100$ AÇAS (M3), 75:25 ham AÇAS:AD (OX)).

Mikroalgal büyüme ile orantılı olarak azot ve fosfor giderimi ve bu sayede atıksu arıtımı amaçlanan bu çalışmada fosfat ve TA giderimlerine ait veriler sırasıyla Şekil 9-10 ve Şekil 1112 'de gösterilmektedir. Mikroalgal yaşam döngüsünün vazgeçilmez makro elementlerinden azot ve fosfor AÇAS içerisinde yeterli düzeyde bulunmaktadır. Azot/fosfor molar oranı 20/1 ile teorik olarak gerekli olan 15,5 değerinden hayli yüksektir. Bu durum fosforun mikroalgal büyümede sınırlayıcı element olarak rol alacağını göstermektedir. Nitekim R1 reaktöründe fosforun tamamen tüketildiği (Şekil 9) kültüvasyonun 10. gününde mikroalgal büyüme de logaritmik büyüme fazından durgun büyüme fazına geçmiştir. Ancak R1 reaktöründe TA gideriminin tamamlanması yaklaşı olarak 5. günün sonunda meydana gelmiştir (Şekil 10). Ortamda TA kalmadığı halde mikroalgal büyümenin devam etmesi karışık mikroalg kültüründe, atmosferden azotu bağlayan türlerin bulunduğunun bir göstergesidir. Benzer durum R2 ve R3 reaktörlerinde de gözlenmiştir. R2 reaktöründe TA'nın tamamen tüketildiği 12 günlük kültüvasyonda fosforun mevcut olması mikroalgal büyümenin devam etmesini sağlamış ancak kısa süreli olsa da günlük biyokütle üretim hızı azalmıştır. Devam eden kültüvasyon boyunca mikroalglerin logaritmik büyüme fazında üremeye devam ettiği söylenebilir. AÇAS içeriğinin yüksek olduğu R3 reaktörüne ise ortamdaki çözünmüş azotun tamamen tüketilmesi 15 günlük kültüvasyon sonunda gerçekleşirken ortamda bulunan fosfor sayesinde mikroalgal büyüme devam etmiştir. AÇAS muhtevasının arttırıldığı R4 ve R5 reaktörleri içinde benzer bir durum söz konusudur. Ortamdaki azotun tüketilmesi yaklaşık 15 gün süre sonunda gerçekleşmiştir. Ortamda çözünmüş formda azot kalmadığı halde logaritmik büyüme fazında meydana gelen mikroalgal büyümenin, reaktör içindeki türlerin baskın olarak atmosferden azotu bağlayabilen ototrofik türlerden meydana geldiğinin bir göstergesidir. Bu duruma benzer şekilde ototrof mikroalg kültürlerinin kullanıldığı bazı çalışmalarda besi ortamındaki toplam azotun (TA) sınırlı tutulmasıyla mikroalg hücrelerin ortamdaki besi eksikliği (azot açlığı) nedeniyle lipit biriktirme eğilimine geçtikleri ve yine hayatta kalabilmek için gerekli azotu atmosferden bağladıkları tespit edilmiştir (Mandal \& Mallick, 2009; Pruvost ve diğ., 2011; Hulatt ve diğ., 2012).

Sonuç olarak ortamda çözünmüş halde bulunan azotun her bir reaktör için tamamen ve TA giderim veriminin $\% 100$ olarak elde edildiği tespit edilmiştir. 


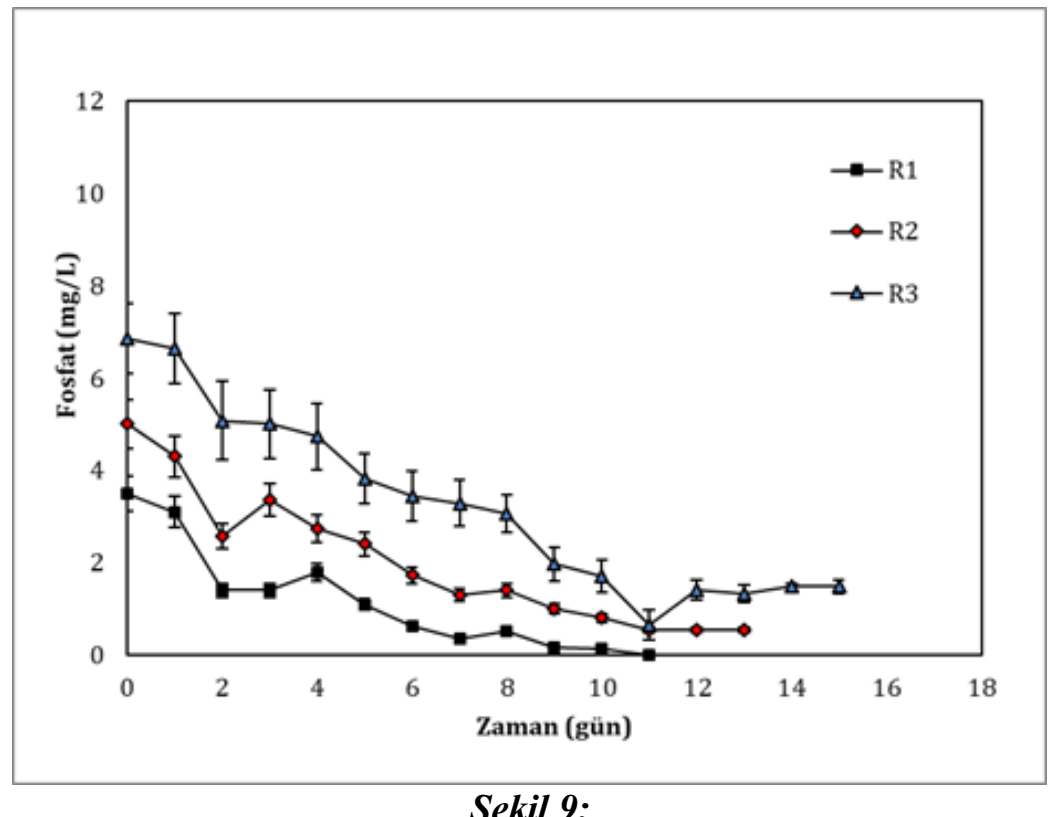

$R 1, R 2$ ve $R 3$ reaktörlerine ait Fosfat giderimi (R1; 10:90 AÇAS:AD, R2; 25:75 $A C ̧ A S: A D, R 3 ; 50: 50 A C ̧ A S: A D)$.

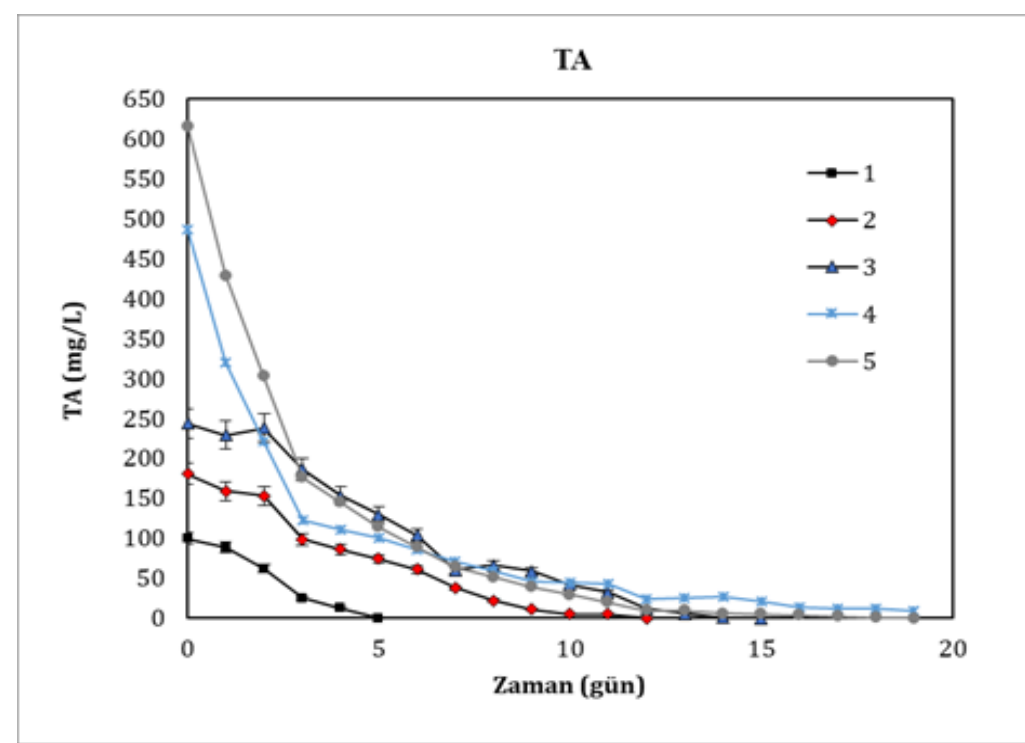

Şekil 10:

R1-R5 reaktörlerine ait TA giderimi (R1; 10:90 AÇAS:AD, R2; 25:75 AÇAS:AD, R3; 50:50 AÇAS:AD)

Mikroalgal biyokütle ve bakteriyel faaliyetin fosfat ve azot giderimi üzerindeki bireysel etkileri sırasıyla Şekil 11 ve Şekil 12 'de gösterilmektedir. M1 reaktöründe 3 gün sonunda gerçekleşen mikroalgal büyümeyle birlikte kademeli bir fosfat giderimi görülmektedir. M2 ve M3 reaktörlerinde ise mikroalgal büyümenin başlaması sırasıyla 9 ve 14 günlük süre sonunda gerçekleşmiş ve bu süre sonunda her iki reaktörde de fosfat giderimi meydana gelmiştir. Bakteriyel faaliyet sonucu meydana gelen giderimleri tanımlamak üzere işletilen OX reaktöründe başlangıçta hızlı bir fosfat giderimi söz konusu iken zaman içinde önemli bir değişim gözlenmemiş ve reaktör içi fosfat miktarı sabit kalmıştır. Başlangıçta meydana gelen bu hızlı giderimin sebebinin çözünmüş formdaki bir kısım fosfatın ortamdaki metallerle bileşik 
oluşturarak (Xia ve Murphy 2016) reaktör tabanına çökelmesi sonucunda meydana geldiği düşünülmektedir. Reaktörlere ait fosfat giderim verimleri M1 reaktörü için $\% 60$, M2 reaktörü için $\% 54,8$, M3 reaktörü için $\% 53,7$ ve OX reaktörü için \%46,6 olarak bulunmuştur.

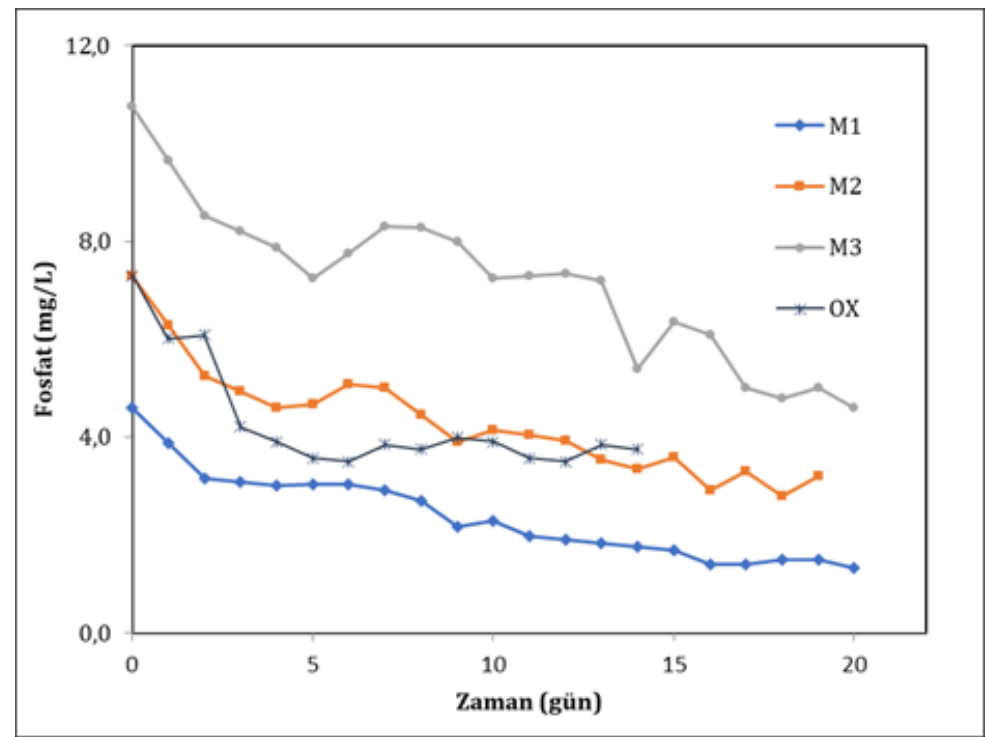

Şekil11:

. M1-M3 ve OX reaktörlerine ait fosfat giderim verimleri (steril AÇAS: AD, 50:50(M1), 75:25(M2), \%100 AÇAS (M3), 75:25 ham AÇAS:AD (OX))

M1-M3 ve OX reaktörlerine ait azot gideriminin gösterildiği Şekil 12 incelendiğinde ortamdaki toplam azotun hızla giderildiği ve yaklaşık on günlük bir süre sonunda ortamda azot kalmadığı tespit edilmiştir.

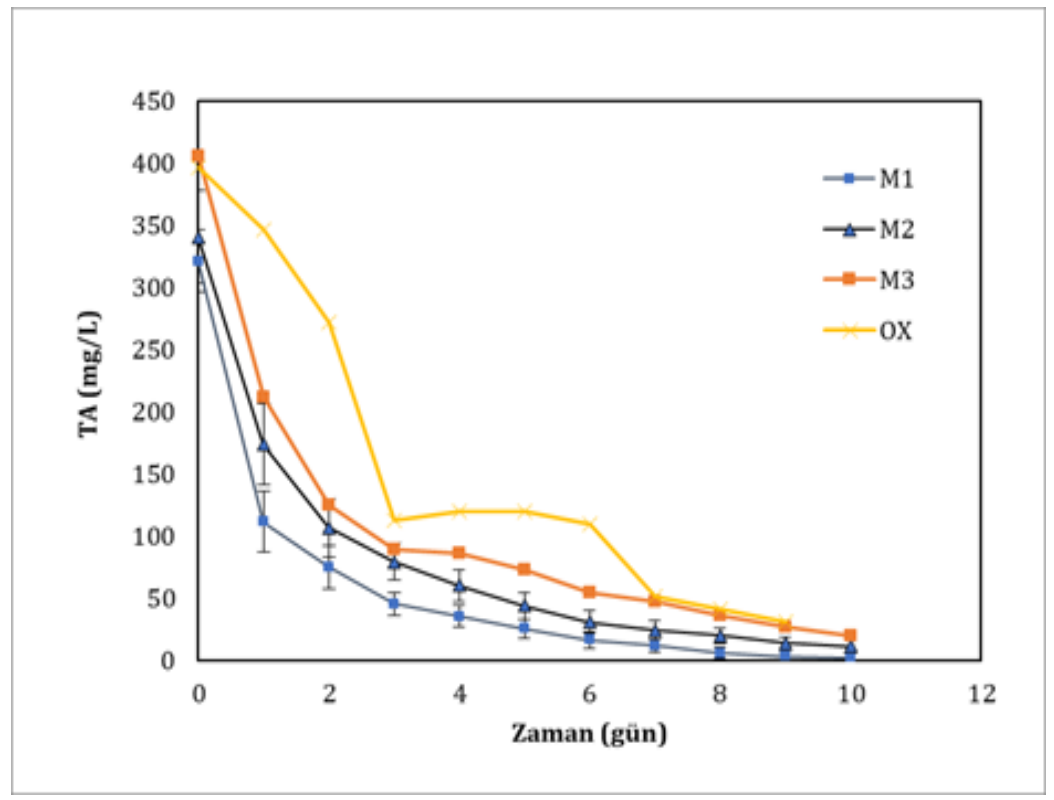

Şekil 12:

M1-M3 ve OX reaktörlerine ait TA giderim verimleri (steril AÇAS: AD, 50:50(MI), 75:25(M2), \%100 AÇAS (M3), 75:25 ham AÇAS:AD (OX)) 
Bakteri-mikroalg faunasının birlikte yetiştirildiği R1-R5 reaktörlerinin kullanıldığ çalışmalarda kullanılan reaktörlerin açı sistem mikroalg üretimini simüle etmesi, kullanılan mikroalg kültürünün karışı olması ve arıtımı amaçlanan AÇAS içeriğinde yüksek konsantrasyonlarda organik karbon içermesi sebebiyle reaktörlerdeki miksotrofik türlerin baskın hale gelmesi beklenmiştir. Ayrıca miksotrofik mikroalg türlerinin özgül büyüme hızlarının ototrofik türlerden yüksek olması yine reaktör içerisinde miksotrofik türlerin baskın hale gelmesini beklememiz için başka bir nedendir (Li ve diğ., 2014; Mohammad Mirzaie et al. 2016). Ancak deneysel çalışmamız süresince kullanılan R1-R5 reaktörlerdeki özgül büyüme hızlarının 0,29-0,59 gün ${ }^{-1}$ ile ototrofik mikroalglerin büyüme hızına yakın olduğu bulunmuştur (Wang et al. 2010; Li et al 2014). Bununla birlikte çalışma süresince ortamda azot kalmadığ 1 halde biyokütle artışının devam etmesi reaktör içerisinde her iki türün de bulunduğunun bir diğer göstergesidir. Diğer taraftan atıksu sterlizasyonu sonrası mikrolag ekimi yapılan M1-M3 reaktörlerinde her ne kadar aşı kültürü içinde miksotrofik türler bulunsa da özgül büyüme hızlarının düştüğü ve ototrofik mikroalg türlerinin baskın hale geldiği görülmüştür.

Mikroalgal biyokütlenin atıksu arıtımı üzerindeki etkilerinin belirlenmesi amacıyla atıksuyun sterilize edilmesi atıksu karakterini büyük oranda değiştirmiş ve bu durum istenilen karşılaştırmanın yapılmasına engel olmuştur. Ancak yine de ayrı şartlarda çalıştırılan sadece mikroalgal biyokütlenin kullanıldığı $\mathrm{M} 2$ ve sadece bakterilerin bulunduğu OX reaktörlerini karşılaştırdığımızda M2 reaktöründe $\% 64,6$ KOİ ve $\% 54,8$ fosfor giderimi elde edilirken OX reaktöründe $\% 45,7$ KOİ ve $\% 46,6$ fosfor giderimi elde edildiği göz önüne alındığında mikroalgal faaliyet sonucu daha etkin bir arıtımın sağlandığı söylenebilir.

Deneysel çalışmalar sonucunda elde edilen giderim verimleri ve reaktörlere ait özgül büyüme hızları Tablo 4'te özetlenmiştir. Genel olarak sonuçlar değerlendirildiğinde özgül büyüme hızı en yüksek olan R1 ve R2 reaktörlerinin KOİ, TOK ve İK giderim hızı R3 rektörüne oranla daha düşük sevilerde kalmış ancak en yüksek fosfat giderim verimi R1 reaktöründe elde edilmiştir. Bununla birlikte \%50 AÇAS içeriğgine sahip R3 reaktörü arıtım verimliliği açısından diğer reaktörlere nazaran fosfor giderimi hariç daha yükssek bir performans göstermiştir.

Tablo 4. Özgül büyüme hızı ve nütrient giderim verimleri

\begin{tabular}{ccccccc}
\hline$\mu\left(\mathrm{gün}^{-1}\right)$ & $\mathrm{KO \dot {I } ( \% )}$ & $\mathrm{TOK}(\%)$ & $\dot{\mathrm{IK}}(\%)$ & $\mathrm{TA}(\%)$ & $\begin{array}{c}\mathrm{PO}_{4}{ }^{3-}-\mathrm{P} \\
(\%)\end{array}$ \\
R1 & 0,59 & 69,4 & 70,8 & 82 & 100 & 100 \\
R2 & 0,54 & 84 & 82,3 & 79,8 & 100 & 89,4 \\
R3 & 0,29 & 87,9 & 86,6 & 84,6 & 100 & 84 \\
R4 & 0,33 & 41,4 & 65 & 86,2 & 100 & 78 \\
R5 & 0,26 & 64,2 & 67,6 & 85 & 100 & 82 \\
M1 & 0,42 & 68,6 & 75,6 & 82,7 & 100 & 60 \\
M2 & 0,34 & 64,6 & 76,9 & 80,3 & 100 & 54,8 \\
M3 & 0,24 & 54,8 & 70,2 & 84,5 & 100 & 53,7 \\
OX & - & 45,7 & 65,8 & 74,5 & 100 & 46,6 \\
\hline
\end{tabular}

AÇAS muhtevasının artması ortamdaki biyolojik parçalanmaya direnç gösteren kirletici miktarının da artmasına neden olmuş ve bu nedenle R4-R5 reaktörlerinde istenilen düzeyde bir arıtım sağlanamamıştır. Ancak R5 reaktöründe yine de \%64,2 KOİ gideriminin yanı sıra \%100 TA giderimi sağlanmıştır. Literatürde yer alan ve anaerobik çürütücü atıksuyunda mikroalgal biyokütle üretimi ve nütrient giderimini inceleyen çalışmalar incelendiğinde, nütrient giderim verimlerinin kullanılan AÇAS muhtevasına, mikroalg türüne ve mikroalgal biyokütlenin yetiştirilme şartlarına bağlı olarak değişim gösterdiği ve KOİ giderim değerinin \%9-78, TA giderim değerinin \%65-91,4 ve fosfat giderim değerinin \%62-98 aralığında değiştiği görülmektedir (Wang et al. 2010; Levine et al. 2011; Tan et al. 2014; Yang et al. 2015; Hajar et al. 2017; Cheng et al. 2016; Deng et al. 2017; Yang et al. 2017). 
Gerçekleştirilen deneysel çalışmalar sonucunda AÇAS artımı için en uygun reaktörün R3 reaktörü olduğu, her ne kadar düşük özgül büyüme hızına sahip olsa da uzun süreli kültüvasyonla istenilen arıtım verimliliğine ulaşılacağı düşünülmektedir. Çalışma sonucunda, R3 reaktörü şartlarının kullanılmasıyla Su Kirliliği Kontrol Yönetmeliği Evsel Nitelikli Atık Suların Alıcı Ortam Deşarj Standartları (Sınıf 3:100000 eşdeğer nüfus) (SKKY, 2004) kriterlere uygun düzeyde bir arıtım sağlanacağı görülmüştür.

\section{SONUÇLAR}

Yapılan çalışmada anaerobik çürütücü atık suyunda, bakteri ve mikroalg kültürlerinin birlikte kullanılması ve AÇAS'ın miksotofik mikroalgal büyüme için elverişli olacak düzeyde arıtma tesisi deşarj suyu kullanılarak seyreltilmesiyle $\% 87,9$ KOİ, $\% 84$ fosfat ve $\% 100$ toplam azot giderimi sağlanmıştır. Bunun yanı sıra mikroalgal biyokütle tarafından sağlanan atık su arıtımının bakteriyel arıtıma nazaran daha etkin olduğu görülmüştür. Aynı şartlar altında mikroalg kültürüyle $\% 64,6$ KOİ ve $\% 54,8$ fosfat giderimi sağlanırken, bakteriyel faaliyet sonucu \%45,7 KOİ ve \%46,6 fosfat giderim verimi elde edilmiştir. Elde edilen sonuçlar değerlendirildiğinde bakteri ve mikroalglerin ortamdaki besi maddelerini tüketmek için rekabete girdikleri ve bu sayede daha etkili bir arıtımın sağlandığı tespit edilmiştir. Çalışmada elde edilen KOİ giderim veriminin, ek bir ileri oksidayon prosesi kullanılarak arttırılmasının mümkün olabileceği düşünülmektedir.

\section{TEŞEKKÜR}

Bu çalışma Gebze Teknik Üniversitesi Bilimsel Araştırma Projeleri BAP 2017-A105-55 kapsamında desteklenmiştir.

\section{KAYNAKLAR}

1. Chang, H., APHA 2005. Standard Methods for the Examination of Water and Wastewater. 21st Edition, American Public Health Association, Washington DC, USA.

2. Bouterfas, R., Belkoura, M., Dauta, A. 2002. Light and temperature effects on the growth rate of three freshwater algae isolated from a eutrophic lake., Hydrobiologia 489, 207-217. doi: 10.1023/A:1023241006464:

3. Cai, T., Ge, X., Park, S. Y., Li, Y. 2013(a). Comparison of Synechocystis sp. PCC6803 and Nannochloropsis salina for lipid production using artificial seawater and nutrients from anaerobic digestion effluent. Bioresource Technology, 144,255-260. doi: 10.1016/j.biortech.2013.06.101.

4. Cai, T., Park, S. Y., Racharaks, R., Li, Y. 2013(b). Cultivation of Nannochloropsis salina using anaerobic digestion effluent as a nutrient source for biofuel production. Applied Energy, 108, 486-492. doi: 10.1016/j.apenergy.2013.03.056

5. Cheng, J., Ye, Q., Xu, J., Yang, Z., Zhou, J., Cen, K. 2016. Improving pollutants removal by microalgae Chlorella PY-ZU1 with $15 \% \mathrm{CO}_{2}$ from undiluted anaerobic digestion effluent of food wastes with ozonation pretreatment. Bioresource Technology, 216, 273-279. doi:10.1016/j.biortech.2016.05.069

6. Cheng, J., Xu, J., Huang, Y., Li, Y., Zhou, J., Cen, K. 2015. Growth optimisation of microalga mutant at high $\mathrm{CO}_{2}$ concentration to purify undiluted anaerobic digestion effluent of swine manure. Bioresource Technology, 177, 240-246. doi: 10.1016/j.biortech.2014.11.099

7. De, bowski M., Szwaja S., Zielin'ski M., Kisielewska M., Stan'czyk-Mazanek E. 2017. The influence of anaerobic digestion effluents (ADEs) used as the nutrient sources for Chlorella 
sp. cultivation on fermentative biogas production. Waste Biomass Valor, 8, 1153-1161. doi: 10.1007/s12649-016-9667-1

8. Deng, X. Y., Gao, K., Zhang, R. C., Addy, M., Lu, Q., Ren, H. Y., ... \& Ruan, R. 2017. Growing Chlorella vulgaris on thermophilic anaerobic digestion swine manure for nutrient removal and biomass production. Bioresource technology, 243, 417-425. doi: 10.1016/j.biortech.2017.06.141

9. Gürol, M. D., Özkan, M., Yatmaz, C., Keriş-Sen, Ü.D., Soydemir, G., Say, N., Sen, Ü. 2013. Mikroalglerden biyodizel üretiminde yenilikçi (innovative) yaklaşımlar, TÜBİTAK 1001 Projesi, Proje No:109Y296.

10. Hajar, H.A.A., Riefler, R.G. and Stuart, B.J., 2016. Anaerobic digestate as a nutrient medium for the growth of the green microalga Neochloris oleoabundans. Environmental Engineering Research, 21(3), 265-275.doi: doi.org/10.4491/eer.2016.005

11. Hajar, H.A.A., Riefler, R.G. and Stuart, B.J., 2017. Cultivation of Scenedesmus dimorphus using anaerobic digestate as a nutrient medium. Bioprocess and biosystems engineering, 40(8), 1197-1207. doi: 10.1007/s00449-017-1780-4

12. Hulatt C. J., Lakaniemi A. M., Puhakka J. A., Thomas D. N. 2012. Energy demands of nitrogen supply in mass cultivation of two commercially important microalgal species, Chlorella vulgaris and Dunaliella tertiolecta. Bioenergy Research, 5(3), 669-684. doi: 10.1007/s12155-011-9175-x

13. Ji, F., Liu, Y., Hao, R., Li, G., Zhou, Y., Dong, R. 2014. Biomass production and nutrients removal by a new microalga strain Desmodesmus sp. in anaerobic digestion wastewater. Bioresource Technology, 161, 200-207. doi:doi.org/10.1016/j.biortech.2014.03.034

14. Keris-Sen, U.D., Sen, U., Soydemir, G. and Gurol, M.D., 2014. An investigation of ultrasound effect on microalgal cell integrity and lipid extraction efficiency. Bioresource technology, 152, 407-413. doi: 10.1016/j.biortech.2013.11.018

15. Keris-Sen, U.D. and Gurol, M.D., 2017. Using ozone for microalgal cell disruption to improve enzymatic saccharification of cellular carbohydrates. Biomass and Bioenergy, 105, 59-65. doi: 10.1016/j.biombioe.2017.06.023

16. Keriş-Şen, Ü. D. 2016. Mikroalglerin sudan ayrıştırılmasında ve biyoetanol üretiminde ozon ve ultrases kullanımı. Doktora Tezi, Gebze Teknik Üniversitesi, Fen Bilimleri Enstitüsü, Kocaeli

17. Kong Q., Li L., Martinez B., Chen P., Ruan R. 2010. Culture of microalgae Chlamydomonas Reinhardtii in wastewater for biomass feedstock production, Applied Biochemistry and Biotechnology, 160 (1), 9-18. doi://doi.org/10.1007/s12010-009-8670-4

18. Levine R. B., Costanza-Robinson M. S., Spatafora G. A. 2011. Neochloris oleoabundans grown on anaerobically digested dairy manure for concomitant nutrient removal and biodiesel feedstock production, Biomass Bioenergy 35, 40-49. doi: 10.1016/j.biombioe.2010.08.035

19. Li, Y., Chen, Y.F., Chen, P., Min, M., Zhou, W., Martinez, B., Zhu, J. and Ruan, R., 2011. Characterization of a microalga Chlorella sp. well adapted to highly concentrated municipal wastewater for nutrient removal and biodiesel production. Bioresource technology, 102(8), 5138-5144. doi: 10.1016/j.biortech.2011.01.091

20. Li Y.R., Tsai W.T., Hsu Y.C., Xie M.Z., Chen J.J. 2014. Comparison of autotrophic and mixotrophic cultivation of green microalgal for biodiesel production. Energy Procedia 52 371-376. doi: 10.1016/j.egypro.2014.07.088 
21. Mandal S., Mallick N. 2009. Microalga Scenedesmus obliquus as a potential source for biodiesel production. Appl Microbiol Biot, 84(2), 281-291.doi: 10.1007/s00253-009-1935-6

22. Mohammad Mirzaie M.A., Kalbasi M., Mousavi S.M., Ghobadian B. 2016. Investigation of mixotrophic, heterotrophic, and autotrophic growth of Chlorella vulgaris under agricultural waste medium. Prep Biochem Biotechnol. 2016;46(2):150-6. doi: 10.1080/10826068.2014.995812

23. Park, J., Jin, H. F., Lim, B. R., Park, K. Y., \& Lee, K. 2010. Ammonia removal from anaerobic digestion effluent of livestock waste using green alga Scenedesmus sp. Bioresource technology, 101(22), 8649-8657. doi: 10.1016/j.biortech.2010.06.142

24. Pittman J. K., Dean A. P., Osundeko O. 2011. The potential of sustainable algal biofuel production using wastewater resources. Bioresource Technology, 102(1), 17-25. doi: 10.1016/j.biortech.2010.06.035

25. Pruvost J., Van Vooren G., Le Gouic B., Couzinet-Mossion A., Legrand J. 2011. Systematic investigation of biomass and lipid productivity by microalgae in photobioreactors for biodiesel application. Bioresource Technology, 102(1), 150-158. doi: 10.1016/j.biortech.2010.06.153

26. Rippka, R., Deruelles, J., Waterbury, J.B., Herdman, M. and Stanier, R.Y., 1979. Generic assignments, strain histories and properties of pure cultures of cyanobacteria. Microbiology, 111(1), pp.1-61. doi: 10.1099/00221287-111-1-1

27. Singh, M., Reynolds, D. L., Das, K. C. 2011. Microalgal system for treatment of effluent from poultry litter anaerobic digestion, Bioresource Technology, 102(23), 10841-10848. doi: 10.1016/j.biortech.2011.09.037

28. Su Kirliliği Kontrolü Yönetmeliği, Resmî Gazete Tarihi: 31.12.2004 Resmî Gazete Sayısı: 25687 http://www.resmigazete.gov.tr/eskiler/2008/02/20080213-13.htm (Erişim Tarihi $12 / 2 / 2019)$

29. Sydney E. B., da Silva T. E., Tokarski A., Novak A. C., de Carvalho J. C., Woiciecohwski A. L., Larroche C., Soccol C. R. 2011. Screening of microalgae with potential for biodiesel production and nutrient removal from treated domestic sewage. Applied Energy, 88 (10), 3291-3294. doi: 10.1016/j.apenergy.2010.11.024

30. Tan, X., Chu, H., Zhang, Y., Yang, L., Zhao, F., Zhou, X. 2014. Chlorella pyrenoidosa cultivation using anaerobic digested starch processing wastewater in an airlift circulation photobioreactor. Bioresource Technology, 170, 538-548. doi: 10.1016/j.biortech.2014.07.086

31. Uggetti, E., Sialve, B., Latrille, E., Steyer, J.-P. 2014. Anaerobic digestate as substrate for microalgae culture: The role of ammonium concentration on the microalgae productivity. Bioresource Technology, 152, 437-443. doi: 10.1016/j.biortech.2013.11.036

32. Vaneeckhaute, C., Meers, E., Michels, E., Christiaens, P., Tack, F. M. G. 2012. Fate of macronutrients in water treatment of digestate using vibrating reversed osmosis, Water, Air, \& Soil Pollution, 223(4), 1593-1603. doi: 10.1007/s11270-011-0967-6

33. Wang, H., Zhang, W., Chen, L., Wang, J., Liu, T. 2013. The contamination and control of biological pollutants in mass cultivation of microalgae. Bioresource Technology, 128, 745750. doi: 10.1016/j.biortech.2012.10.158

34. Wang, L., Wang, Y., Chen, P., Ruan, R. 2010. Semi-continuous cultivation of Chlorella vulgaris for treating undigested and digested dairy manures, Applied Biochemistry and Biotechnology, 162(8), 2324-2332. doi: 10.1007/s12010-010-9005-1 
35. Xia, A., Murphy, J. D. 2016. Microalgal cultivation in treating liquid digestate from biogas systems. Trends in Biotechnology, 34(4), 264-275. doi: 10.1016/j.tibtech.2015.12.010

36. Xu, J., Zhao, Y., Zhao, G., Zhang, H. 2015. Nutrient removal and biogas upgrading by integrating freshwater algae cultivation with piggery anaerobic digestate liquid treatment. Applied Microbiology and Biotechnology, 99(15), 6493-6501.doi:10.1007/s00253-015$6537-\mathrm{x}$

37. Yang, S., Xu, J., Wang, Z.M., Bao, L.J. and Zeng, E.Y., 2017. Cultivation of oleaginous microalgae for removal of nutrients and heavy metals from biogas digestates. Journal of Cleaner Production, 164, 793-803. doi: 10.1016/j.jclepro.2017.06.221

38. Yang, L., Tan, X., Li, D., Chu, H., Zhou, X., Zhang, Y., \& Yu, H. 2015. Nutrients removal and lipids production by Chlorella pyrenoidosa cultivation using anaerobic digested starch wastewater and alcohol wastewater. Bioresource technology, 181, 54-61. doi: 10.1016/j.biortech.2015.01.043 